\title{
Estimation of Nitrogen-corrected Metabolizable Energy Value of Laboratory Canine Diets
}

\author{
Seinosuke OHSHIMA, Yoshinori FUKUMA, Toshiaki SUZUKI, \\ and Matanobu ABE* \begin{abstract}
Tsukuba-shi, Ibaraki 300-33 and "School of Veterinary Medicine, Azabu University, 1-17-71 Fuchinobe, Sagamihara-shi, Kanagawa 229, Japan
\end{abstract} \\ Tsukuba Research Branch, Research Center, Nihon Nosan Kogyo K.K., 5,246 Takura,
}

(Received 19 February 1993/Accepted 26 May 1993)

\begin{abstract}
This study evaluates the reliability of the equation, metabolizable energy $(\mathrm{ME})=$ digestible energy $(\mathrm{DE})-1.25 \times$ digestible crude protein $(\mathrm{DCP})$, as a means of estimating the energy value of non-purified diets for laboratory dogs. To do this, five digestion and nitrogen-balance (NB) trials and determination of the energy value of a diet were conducted using five diets and four mature, male Beagles for each experiment. The resulting digestibility of crude protein, acid ether extract, and nitrogen-free extract of these diets were $79.5 \%, 91.6 \%$, and $84.8 \%$, respectively. The NB in every diet was positive : $1.4 \sim 8.6 \mathrm{mg} / \mathrm{g}$ dry matter of ingested diet. Of the nitrogen $(\mathrm{N})$ ingested, $21 \%$ was excreted into feces, $66 \%$ was excreted into urine, and $13 \%$ was retained. In terms of dietary gross energy $(\mathrm{GE}), 18 \%$ was lost in feces and $5 \%$ was excreted into urine leaving $77 \%$ as ME. Retained energy in the body was only $1 \%$, and N-corrected metabolizable energy (MEn) was $76 \%$ of GE. The average urinary energy (UE) loss per gram of urinary $\mathrm{N}$ was $7.84 \mathrm{kcal}$. The correlation between $\mathrm{UE} / \mathrm{DCP}$ and $\mathrm{NB}$ values is statistically significant : UE/DCP $=1.24-0.03 \mathrm{NB}, \mathrm{r}=0.798, \mathrm{P}<0.001$. Therefore, UE $/ \mathrm{DCP}$ is $1.24 \mathrm{kcal} / \mathrm{g}$ at $\mathrm{N}$-equilibrium, almost the same as the factor in the above equation. The $\mathrm{ME}$ value calculated by the equation is identical to the MEn value, and both are significantly lower $(\mathrm{P}<0.05)$ than the empirically determined $\mathrm{ME}$ value. We conclude that this equation should be expressed as MEn $=\mathrm{DE}-1.25 \mathrm{DCP}$, and is a reliable and convenient means of estimating the MEn of diets. Also, this study demonstrates that this revised equation can be applied, in the case of dogs, not only at $\mathrm{N}$-equilibrium but also when $\mathrm{N}$ is retained in the body.- KEY WORDS : dietary energy, dog, nitrogen-corrected metabolizable energy, nitrogen-equilibrium, non-purified laboratory diet
\end{abstract}

Recently, Suzuki et al. [14] recommended using nitrogen $(\mathrm{N})$-corrected metabolizable energy (MEn) to evaluate energy in nonpurified diets for laboratory animals, including canine diets. However, the determination of MEn involves laborious and time-consuming processes, such as collection of all urine excreted, removal of hair and dust, freeze-drying of urine, analysis of urinary nitrogen, and determination of urinary energy using an adiabatic bomb calorimeter. To estimate the metabolizable energy (ME) value, researchers (Kendall et al. [6], Hirakawa and Baker [5], and Finke [3]) have proposed using the equation of $\mathrm{ME}=\mathrm{DE}-1.25 \mathrm{DCP}$, where $\mathrm{DE}$ is digestible energy and DCP is digestible crude protein determined empirically. Before adopting this equation in the case of dogs, three items should be considered :

(1) how the equation was actually derived as a means of evaluating dietary energy values ;

(2) whether the calculated $\mathrm{ME}$ value (cME) using the equation is equal to the values of determined ME or MEn ;

(3) use of 1.25 as the DCP factor.

In spite of this, however, Czarnecki-Maulden et al. [2] evaluated the validity of this equation in research supported by the Pet Food Institute of the U.S.A.

The present work was designed to ascertain the reliability of the equation as a means of estimating MEn. For this purpose, five diges- 
tion and nitrogen-balance (NB) trials and determination of energy value of a diet were conducted using five non-purified, dry diets and four mature, male Beagles for each experiment.

\section{Materials and Methods}

Experiments and diets: In this study, experiments were conducted using five diets : one (Experiment (Expt.) 1) was specially prepared, and four (Expts. $2 \sim 5$ ) were commercially available dry diets for laboratory dogs (Nihon Nosan Kogyo K. K.). The formula of the diet used in Expt. 1 is shown in Table 1 and is similar to the proprietary formulation used in Expts. $2 \sim 5$. All the diets were obtained by first processing the mash, except for fat component (extra fancy tallow). The mash was processed into expanded pellets using an extruder for $3-4 \mathrm{~min}$. at around $120-130^{\circ} \mathrm{C}$ under $30 \%$ moisture. The pellets were then dried to approximately $10 \%$ moisture. The surface of the processed diet was then sprayed with liquefied fat. The diets were then crushed using a hammer-mill, and $0.3 \% \mathrm{Cr}_{2} \mathrm{O}_{3}$ was added as an index for determining digestibility and energy content through a $1.5 \mathrm{~mm}$ screen. Table 2 shows the chemical analysis of all five diets. At 10 AM each day, each dog was fed $250 \mathrm{~g}$ of the crushed diet, which was first added to $120 \mathrm{ml}$ of warm water and then kneaded to form a stiff mixture. Drinking water was available at all times to each animal.

Animals : In Expts. $1 \sim 3$, four mature, male Beagles (each weighing an average $15 \mathrm{~kg}$ ) from one litter were used, and in Expts. 4 and 5 , four (each weighing an average $12 \mathrm{~kg}$ ) from another litter were used. These two litters were bred in the same colony.

Collection of feces and urine : The animals were individually housed in metabolism cages $(\mathrm{H} \times \mathrm{L} \times \mathrm{W}: 75 \times 70 \times 75 \mathrm{~cm})$ equipped with a metal drain-board floor. In each Expt., a 5day preliminary period for the preparatory test was followed by a 4-day period for the independent collection of feces and urine. Feces were dried at approximately $65^{\circ} \mathrm{C}$ and then placed in a room to reach equilibrium in terms of moisture content. Hair was then removed from the dried feces by crushing it through a $1 \mathrm{~mm}$ screen. Urine was collected in a bottle containing $5 \mathrm{~m} \ell$ of $5 \%(\mathrm{v} / \mathrm{v}) \mathrm{H}_{2} \mathrm{SO}_{4}$ solution. A por-
Table 1. Composition of the experimental diet used in Expt. 1

\begin{tabular}{lr}
\hline Ingredients & \multicolumn{1}{c}{$\%$} \\
\hline Corn & 40.00 \\
Milo & 7.00 \\
Dried bakery products & 5.00 \\
Wheat bran & 6.00 \\
Rice bran, solvent extracted & 4.00 \\
White fish meal & 5.00 \\
Meat and bone meal & 10.00 \\
Gelatin by-product & 1.00 \\
Soybean oil meal, solvent extracted & 3.25 \\
Corn gluten meal & 4.00 \\
Torula dried yeast & 2.00 \\
Roasted soybean flour (kinako) & 7.00 \\
Salt & 1.00 \\
Extra fancy tallow & 4.00 \\
Vitamin and mineral mixture & 0.75 \\
\hline Total & 100.00 \\
\hline
\end{tabular}

* The premix contained per kilogram 3,000,000 I.U. vitamin $\mathrm{A}, 600,000$ I.U. vitamin $\mathrm{D}_{3}, 12,000$ I.U. vitamin E, $520 \mathrm{mg}$ vitamin $\mathrm{K}_{3}, 350 \mathrm{mg}$ thiamine, $530 \mathrm{mg}$ riboflavin, $2,500 \mathrm{mg}$ niacin, $250 \mathrm{mg}$ pyridoxine, $3.4 \mathrm{mg}$ calcium pantothenate, $6.0 \mathrm{mg}$ vitamin $\mathrm{B}_{12}, 20 \mathrm{mg}$ biotin, $68 \mathrm{mg}$ choline chloride, $45 \mathrm{mg}$ folic acid, 1,070 $\mathrm{mg} \mathrm{Mn}, 11.0 \mathrm{mg} \mathrm{Fe}, 500 \mathrm{mg} \mathrm{Co}, 10.0 \mathrm{mg} \mathrm{Zn}$ and 320 mg I.

Table 2. Chemical analysis (\% dry matter basis) of the diets ${ }^{11}$

\begin{tabular}{cccccc}
\hline Expt. & $\begin{array}{c}\text { Crude } \\
\text { protein }\end{array}$ & AEE $^{2)}$ & NFE $^{3)}$ & $\begin{array}{c}\text { Carbo- } \\
\text { hydrate }\end{array}$ & $\begin{array}{c}\text { Crude } \\
\text { ash }\end{array}$ \\
\hline 1 & 26.4 & 11.9 & 50.7 & 54.1 & 7.6 \\
2 & 26.8 & 11.9 & 48.8 & 52.8 & 8.5 \\
3 & 28.6 & 8.9 & 50.0 & 53.3 & 9.2 \\
4 & 27.2 & 9.8 & 50.7 & 54.6 & 8.4 \\
5 & 24.2 & 9.5 & 51.5 & 56.7 & 9.6 \\
\hline
\end{tabular}

1) Dry matter $(\%)$ of the diets used in Expts. 1-5 was $90.0,91.5,90.6,92.2$, and 91.0 , respectively,

Acid ether extract

4) NFE + Crude fiber

3) Nitrogen-free extract

tion of this collected urine was neutralized with $\mathrm{NaOH}$ and then freeze-dried for calorimetry.

Chemical analysis: Proximate analysis was conducted on the diets and collected feces using official Japanese methods [10], with the exception of crude fat analysis, which was determined according to the AOAC [1] as acid ether extract (AEE). Only the $\mathrm{N}$-free extract (NFE) was calculated by subtraction of the 
proximate analysis from $100 \%$. As for extruded diets, the usage of AEE in the calculation of NFE is standard for the official Japanese method [10]. Moreover, it is recommended by the AOAC [1]. The $\mathrm{Cr}_{2} \mathrm{O}_{3}$ contents of the diets and feces were determined at $444 \mathrm{~nm}$ in accordance with Hill and Anderson [4] using a spectrophotometer (Spectronic 20A, Shimazu Co.). The caloric contents of the diets, dried feces, and urine were determined using an adiabatic bomb calorimeter (OSK150, Ogawa Co.).

Determination of MEn : According to the National Research Council (NRC) [12], the MEn (in units of kcal per gram of ingested dry matter $(\mathrm{DM}))$ is defined by

$$
\begin{aligned}
\mathrm{MEn}=\mathrm{GE}- & (\mathrm{FE}+\mathrm{UE}) \\
& -(\mathrm{NB} \times \mathrm{UE} / \mathrm{UN}),
\end{aligned}
$$

where GE is the gross energy of a diet, FE and $\mathrm{UE}$ are the energy of feces and urine $(\mathrm{kcal} / \mathrm{g}$ of ingested $\mathrm{DM})$, respectively, $\mathrm{NB}$ is the $\mathrm{N}$-balance or nitrogen $(\mathrm{g})$ retained per gram of in- gested DM and UN is the urinary nitrogen ( $\mathrm{g}$ of ingested $\mathrm{DM}$ ) .

Definition of cME:In this work we defined $\mathrm{cME}$ as the $\mathrm{ME}$ value calculated by [3, $5,6]$

$$
\mathrm{cME}=\mathrm{DE}-1.25 \mathrm{DCP} \text {. }
$$

\section{Results}

Apparent digestibility of dietary nutrients: Table 3 shows the apparent digestibility of the dietary nutrients in each diet. The mean and standard deviation of the values for the digestibility of DM, crude protein (CP), AEE, $\mathrm{NFE}$, and carbohydrate were $78.2 \pm 2.0 \%, 79.5$ $\pm 2.1 \%, 91.6 \pm 1.8 \%, 84.8 \pm 3.6 \%$, and 81.4 $\pm 3.8 \%$, respectively. The mean digestibility values for $\mathrm{CP}, \mathrm{AEE}$, and NFE were in good agreement with those adopted by the NRC (i. e., $80 \%, 90 \%$, and $85 \%$, respectively) [13]

$\mathrm{N}$-balance : As shown in Table 4, the NB in each diet was slightly positive, and the $\mathrm{N}-$

Table 3. Apparent digestibility $(\%)$ of dietary nutrients in the diets used in Expts. 1-5 (Means \pm S.D. ${ }^{11}$ )

\begin{tabular}{ccccccc}
\hline Expt. & $\begin{array}{c}\text { Number of } \\
\text { dogs used }\end{array}$ & $\begin{array}{c}\text { Dry } \\
\text { matter }\end{array}$ & $\begin{array}{c}\text { Crude } \\
\text { protein }\end{array}$ & AEE $^{2)}$ & NFE $^{3)}$ & $\begin{array}{c}\text { Carbo- } \\
\text { hydrate }^{4)}\end{array}$ \\
\hline 1 & 4 & $77.4 \pm 0.4$ & $76.1 \pm 0.4$ & $93.8 \pm 0.4$ & $79.2 \pm 0.7$ & $75.8 \pm 0.8$ \\
2 & 4 & $79.8 \pm 0.8$ & $82.3 \pm 1.1$ & $92.9 \pm 0.3$ & $86.3 \pm 1.0$ & $83.3 \pm 0.9$ \\
3 & 4 & $76.3 \pm 0.5$ & $78.3 \pm 1.1$ & $88.6 \pm 0.8$ & $85.2 \pm 0.3$ & $82.7 \pm 0.2$ \\
4 & 4 & $81.2 \pm 0.8$ & $80.9 \pm 0.9$ & $92.0 \pm 0.9$ & $90.0 \pm 0.8$ & $86.8 \pm 1.1$ \\
5 & 4 & $76.4 \pm 1.4$ & $79.7 \pm 0.7$ & $90.9 \pm 0.5$ & $83.2 \pm 1.9$ & $78.6 \pm 2.2$ \\
\hline & Mean \pm SD & $78.2 \pm 2.0$ & $79.5 \pm 2.1$ & $91.6 \pm 1.8$ & $84.8 \pm 3.6$ & $81.4 \pm 3.8$ \\
\hline
\end{tabular}

1) Standard deviation $2), 3), 4)$ Same as in Table 2

Table 4. Nitrogen $(\mathrm{N})$-balance (mg/g dry matter of diet) for each diet (Means \pm S.D. $\left.{ }^{1)}\right)$

\begin{tabular}{lccrcc}
\hline \multirow{2}{*}{ Expt. } & $\begin{array}{c}\text { Number } \\
\text { of } \\
\text { dogs }\end{array}$ & N-intake & \multicolumn{2}{c}{ N-excretion } & N-retention \\
\cline { 4 - 5 } & 4 & 42.3 & $10.1 \pm 0.2$ & $23.6 \pm 1.6$ & $8.6 \pm 1.8$ \\
\hline 1 & 4 & 43.0 & $7.6 \pm 0.5$ & $29.4 \pm 2.4$ & $6.0 \pm 2.8$ \\
2 & 4 & 45.9 & $10.0 \pm 0.5$ & $32.7 \pm 1.5$ & $3.3 \pm 2.0$ \\
3 & 4 & 43.6 & $8.3 \pm 0.5$ & $26.8 \pm 1.3$ & $8.4 \pm 1.2$ \\
4 & 4 & 38.6 & $7.8 \pm 0.2$ & $29.4 \pm 2.7$ & $1.4 \pm 2.8$ \\
5 & 42.7 & $8.8 \pm 1.1$ & $28.4 \pm 3.0$ & $5.5 \pm 2.8$ \\
\hline $\begin{array}{l}\text { Mean } \\
\%\end{array}$ & 100 & $21 \pm 2$ & $66 \pm 7$ & $13 \pm 7$ \\
\hline
\end{tabular}

1) Standard deviation 
Table 5. Urinary energy per urinary nitrogen $(N)$, per urinary $N \times 6.25$, and per digestible crude protein $(\mathrm{kcal} / \mathrm{g})$

\begin{tabular}{|c|c|c|c|c|}
\hline Expt. & $\begin{array}{l}\text { Number of } \\
\text { dogs used }\end{array}$ & $\mathrm{UE} / \mathrm{UN}^{2)}$ & $\mathrm{UE} / \mathrm{UN} \times 6.25^{3)}$ & $\mathrm{UE} / \mathrm{DCP}^{4)}$ \\
\hline 1 & 4 & $8.97 \pm 0.27$ & $1.43 \pm 0.04$ & $1.05 \pm 0.08$ \\
\hline 2 & 4 & $7.77 \pm 0.30$ & $1.24 \pm 0.05$ & $1.03 \pm 0.10$ \\
\hline 3 & 4 & $8.11 \pm 0.19$ & $1.30 \pm 0.03$ & $1.19 \pm 0.05$ \\
\hline 4 & 4 & $6.89 \pm 0.43$ & $1.10 \pm 0.07$ & $0.84 \pm 0.09$ \\
\hline \multirow[t]{2}{*}{5} & 4 & $7.48 \pm 0.59$ & $1.20 \pm 0.10$ & $1.14 \pm 0.15$ \\
\hline & Mean \pm S.D. & $7.84 \pm 0.77$ & $1.25 \pm 0.12$ & $1.05 \pm 0.13$ \\
\hline
\end{tabular}

1) Standard deviation

2) Urinary energy/urinary $\mathrm{N}$

3) Urinary energy/

urinary $\mathrm{N} \times 6.25$

4) Urinary energy/ingested digestible crude protein

Table 6. Distribution of dietary energy and the calculated metabolizable energy for each diet used in Expts. 1-5 ( $\mathrm{kcal} / \mathrm{g}$ dry matter of diet) $\left(\right.$ Mean \pm S.D. $\left.{ }^{1)}\right)$

\begin{tabular}{|c|c|c|c|c|c|c|c|c|c|}
\hline Expt. & $\begin{array}{l}\text { Number of } \\
\text { dogs used }\end{array}$ & $\mathrm{GE}^{2)}$ & $\mathrm{FE}^{3)}$ & $\mathrm{DE}^{4)}$ & $\mathrm{UE}^{5)}$ & $\mathrm{ME}^{6)}$ & $\mathrm{NB}^{7)} \times \mathrm{UE} / \mathrm{UN}^{8)}$ & $\mathrm{MEn}^{9)}$ & $\mathrm{cME}^{(0)}$ \\
\hline 1 & 4 & 4.96 & $0.95 \pm 0.02$ & $4.01 \pm 0.02$ & $0.21 \pm 0.01$ & $3.80 \pm 0.03$ & $0.08 \pm 0.01$ & $3.72 \pm 0.02$ & 3.76 \\
\hline 2 & 4 & 4.80 & $0.78 \pm 0.03$ & $4.02 \pm 0.03$ & $0.23 \pm 0.02$ & $3.79 \pm 0.04$ & $0.05 \pm 0.02$ & $3.74 \pm 0.02$ & 3.75 \\
\hline 3 & 4 & 4.65 & $0.88 \pm 0.04$ & $3.77 \pm 0.04$ & $0.27 \pm 0.01$ & $3.50 \pm 0.03$ & $0.03 \pm 0.02$ & $3.47 \pm 0.02$ & 3.47 \\
\hline 4 & 4 & 4.54 & $0.72 \pm 0.03$ & $3.82 \pm 0.03$ & $0.18 \pm 0.02$ & $3.64 \pm 0.03$ & $0.05 \pm 0.01$ & $3.59 \pm 0.03$ & 3.54 \\
\hline 5 & 4 & 4.49 & $0.94 \pm 0.06$ & $3.55 \pm 0.06$ & $0.22 \pm 0.02$ & $3.33 \pm 0.07$ & $0.01 \pm 0.02$ & $3.32 \pm 0.06$ & 3.31 \\
\hline \multirow{2}{*}{\multicolumn{2}{|c|}{$\begin{array}{c}\text { Mean } \pm \text { S.D. } \\
\% \text { of } \mathrm{GE}\end{array}$}} & $4.69 \pm 0.17$ & $0.85 \pm 0.09$ & $3.83 \pm 0.17$ & $0.22 \pm 0.03$ & $3.61 \pm 0.18^{*}$ & $0.04 \pm 0.02$ & $3.57 \pm 0.16^{*}$ & $3.57 \pm 0.17^{*}$ \\
\hline & & 100 & $18 \pm 2$ & $82 \pm 2$ & $5 \pm 1$ & $77 \pm 2$ & $1 \pm 0$ & $76 \pm 2$ & - \\
\hline
\end{tabular}

1) Standard deviation 2) Gross energy 3) Fecal energy 4) Digestible energy 5) Urinary
energy 6) Metabolizable energy 7) Nitrogen balance 8) This overall formula means urinary energy loss assumed for the metabolism of retained nitrogen 9) Nitrogen-corrected metabolizable energy 10) Calculated metabolizable energy obtained using $\mathrm{cME}=\mathrm{DE}-1.25 \mathrm{DCP}$ * There were significant differences $(\mathrm{P}<0.05)$ between $\mathrm{ME}$ and $\mathrm{MEn}$, and between $\mathrm{ME}$ and $\mathrm{cME}$.

retention level ranged from 1.4 to $8.6 \mathrm{mg} / \mathrm{g}$ $\mathrm{DM}$. Of the $\mathrm{N}$ ingested, $21 \%$ on average was excreted into feces, $66 \%$ was excreted into urine, and $13 \%$ was retained. The $\mathrm{N}$-balance is affected not only by the physiological condition of an animal but also by dietary factors, such as the biological value of protein. Despite the similar chemical composition of the diets (Table 2), a considerable difference in $\mathrm{N}$ retention was detected among the diets. This is attributable, at least in part, to the difference in dietary ingredients and their formulation.

Dietary energy: Table 5 shows that the UE loss per UN, per 6.25UN and per ingested $\mathrm{DCP}$, were $7.84,1.25$, and $1.05 \mathrm{kcal} / \mathrm{g}$, on average, respectively.

Table 6 shows the values of $\mathrm{DE}, \mathrm{ME}$ and MEn obtained for each diet, and the values of all parameters in the MEn equation (1). Of the dietary GE $(4.69 \mathrm{kcal} / \mathrm{g} \mathrm{DM})$, an average of 18
$\%(0.85 \mathrm{kcal} / \mathrm{g} \mathrm{DM})$ was lost in feces, $5 \%(0.22$ $\mathrm{kcal} / \mathrm{g} \mathrm{DM}$ ) was excreted into urine, and $77 \%$ $(3.61 \mathrm{kcal} / \mathrm{g}$ DM) was ME. A one percent equivalent of the $\mathrm{GE}$ was retained in the body, and this portion $(0.04 \mathrm{kcal} / \mathrm{g} \mathrm{DM})$ would be lost in urine without being incorporated into body tissues at $\mathrm{N}$-equilibrium. Therefore, the MEn was an average of $76 \%(3.57 \mathrm{kcal} / \mathrm{g} \mathrm{DM})$ of the dietary GE. The ME values correlated highly $(\mathrm{P}<0.01)$ with the MEn values $(\mathrm{ME}=$ $-0.46+1.14 \mathrm{MEn}$, at $\mathrm{r}=0.998)$. But, the $\mathrm{ME}$ values were always higher, an average of $40 \mathrm{kcal} / \mathrm{kg}$ diet, than those of MEn, and there was a significant difference $(\mathrm{P}<0.05)$ between the means. The values of $\mathrm{cME}$ correlated highly $(\mathrm{P}<0.01)$ with the MEn values and there was no significant difference between them $(\mathrm{cME}=-0.30+1.08 \mathrm{MEn}$, at $\mathrm{r}=0.988)$. The cME values obtained using equation (2) are almost identical to the MEn values. 


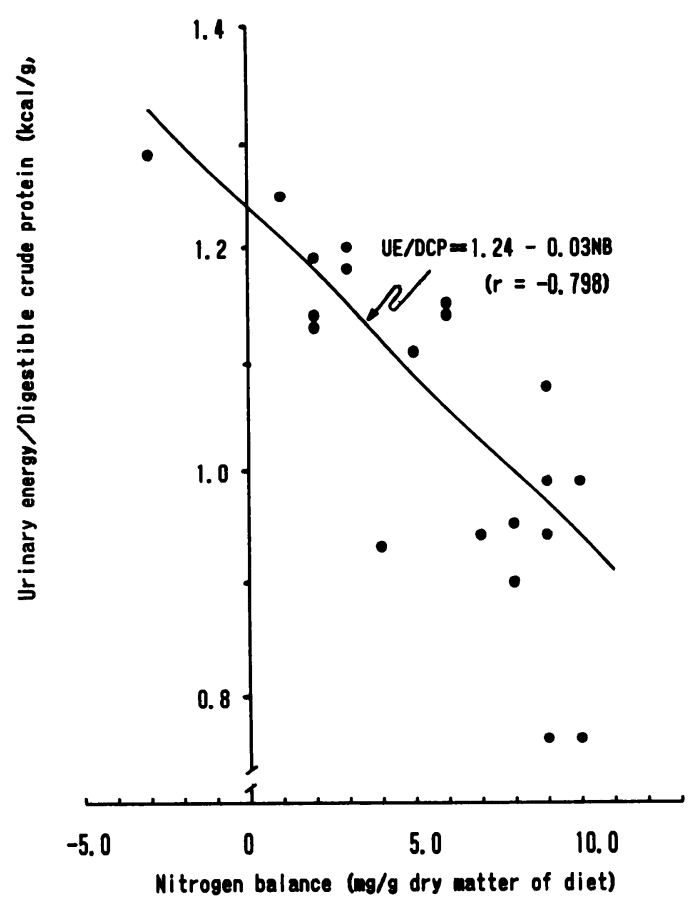

Fig. 1. Correlation between urinary energy per ingested digestible crude protein (UE/DCP) and nitrogen balance (NB)

In Fig. 1, the UE/DCP is plotted against $\mathrm{NB}$ for each dog in every experiment. The correlation between UE/DCP and NB is statistically significant : $r=0.798$ at $P<0.001$. Linear regression analysis yielded the relationship $(\mathrm{UE} / \mathrm{DCP}=1.24-0.03 \mathrm{NB})$. According to this relationship, $\mathrm{UE} / \mathrm{DCP}$ at $\mathrm{N}$-equilibrium $(\mathrm{NB}=$ 0 ) is $1.24 \mathrm{kcal} / \mathrm{g}$, with $95 \%$ confidence limits ranging between 1.02 and $1.45 \mathrm{kcal} / \mathrm{g}$.

\section{Discussion}

Other than those of Suzuki et al. [14] and of Hirakawa and Baker [5], there are few reports concerning the ME or MEn values of canine diets. Hirakawa and Baker [5] determined GE, FE, UE, and N-retention using growing puppies, however, did not report MEn but cME using the equation (2). They showed that the cME value was in good agreement with the ME value determined empirically, and thus asserted the validity of this equation (2). Although they did not report the MEn value, it can be calculated from their data. The MEn value thus obtained was $91 \mathrm{kcal} / \mathrm{kg}$ lower on the average than the determined $\mathrm{ME}(\mathrm{P}<0.05)$, and the difference was equivalent to $3 \%$ of MEn. In the present study using mature dogs, the MEn was also significantly lower $(\mathrm{P}<0.05)$ than the determined $\mathrm{ME}$, but the difference was only $40 \mathrm{kcal} / \mathrm{kg}$, which was equivalent to 1 $\%$ of MEn. This was due to the fact that $\mathrm{N}-$ retention of the total $\mathrm{N}$ ingested was $13 \%$ in the present study, in contrast to $47 \%$ in the work by Hirakawa and Baker [5]. Because N-retention is higher in growing puppies than in mature dogs, the difference between ME and MEn is greater in the former than in the latter. Theoretically, the ME value is affected by the Nretention of each animal. Since the energy value of a diet should not be affected by the physiological condition of an animal, it is recommended that the MEn values be used.

The factor 1.25 in the equation (2) was originally derived from the studies by Atwater, who obtained $7.9 \mathrm{kcal}$ of UE per gram of UN in men receiving mixed diets $[7,8]$. The value of $\mathrm{UE} / 6.25 \mathrm{UN}$ is identical to UE per ingested $\mathrm{DCP}$ or UE per gram of absorbed protein at $\mathrm{N}$ equilibrium or at zero $\mathrm{N}$-retention $(\mathrm{NB}=0)$. Thus, the value of $1.25 \mathrm{kcal} / \mathrm{g} \mathrm{DCP}$ was obtained from rounding the value of the ratio, 7.9/6.25 [7]. This factor may differ depending on respective animals $[9,12]$. For dogs, the NRC [11] adopted 1.25 for correction of the energy estimation of $\mathrm{CP}$ from $\mathrm{DE}$ to $\mathrm{ME}$ by calculation. Kendall et al. [6], however, stated that this application is somewhat arbitrary. According to the NRC [12], Rubner obtained the value of $7.45 \mathrm{kcal} / \mathrm{g}$ for $\mathrm{UE} / \mathrm{UN}$ for dogs in 1885 . When divided by 6.25 , this value becomes $1.19 \mathrm{kcal} / \mathrm{g}$ for UE/DCP. The discrepancy between these two values (i.e., 1.19 and $1.25 \mathrm{kcal} / \mathrm{g}$ ) may be explained by the difference in N-retention of animals used; Fig. 1 clearly shows that UE/DCP decreases with increased $\mathrm{N}$-retention. The value of UE/DCP at zero $\mathrm{N}$-retention is $1.24 \mathrm{kcal} / \mathrm{g}$, in good agreement with the factor 1.25 adopted by the NRC [11]. Fig. 1 illustrates that equation (2) can be applied to animals at $\mathrm{N}$-equilibrium.

When animals are at $\mathrm{N}$-equilibrium, the following relationships are applied :

$$
\mathrm{ME}=\mathrm{MEn}=\mathrm{DE}-\mathrm{UE}
$$$$
\mathrm{UE} / \mathrm{DCP}=1.25 \text {. }
$$

Therefore,

$$
\mathrm{ME}=\mathrm{MEn}=\mathrm{DE}-1.25 \mathrm{DCP} .
$$

Moreover, the equation (2) can be applied to 
animals which retain $\mathrm{N}$ in their body or not at $\mathrm{N}$-equilibrium. By definition,

$$
\mathrm{DCP}=(\mathrm{IN}-\mathrm{FN}) \times 6.25 \text {, }
$$

where IN is ingested $\mathrm{N}$ and $\mathrm{FN}$ is fecal $\mathrm{N}$.

Also, by definition,

$$
\mathrm{NB}=(\mathrm{IN}-\mathrm{FN})-\mathrm{UN} \text {. }
$$

Then, from equation (3) and (4),

$$
\mathrm{NB}=\mathrm{DCP} / 6.25-\mathrm{UN} \text {. }
$$

From this equation,

$$
\mathrm{NB} / \mathrm{UN}=\mathrm{DCP} / \mathrm{UN} \cdot 6.25-1 \text {. }
$$

By difining $\mathrm{DE}$ as $\mathrm{DE}=\mathrm{GE}-\mathrm{FE}$, the equation (1) becomes

$$
\mathrm{MEn}=\mathrm{DE}-\mathrm{UE}(1+\mathrm{NB} / \mathrm{UN}) .
$$

Then, substituting the equation (5) into this expression yields

$$
\mathrm{MEn}=\mathrm{DE}-\mathrm{UE} \cdot \mathrm{DCP} / 6.25 \mathrm{UN} \text {. }
$$

If we use the results shown in Table 5 , i.e. that $\mathrm{UE} / 6.25 \mathrm{UN}=1.25$, then, our final equation is :

$$
\mathrm{MEn}=\mathrm{DE}-1.25 \mathrm{DCP} \text {. }
$$

This transformation demonstrates that when corrected to the $\mathrm{N}$-equilibrium state the total urinary energy loss is constant, even in animals which retain $\mathrm{N}$.

The present study demonstrates that dietary MEn can be estimated conveniently using the equation $\mathrm{MEn}=\mathrm{DE}-1.25 \mathrm{DCP}$ for growing as well as for mature dogs. Strictly speaking, however, further study using growing dogs may be necessary to demonstrate the DCP factor. Moreover, use of this equation still requires collection of feces and determination of fecal energy. For greater convenience, the NRC [13] proposed another method based on proximate analysis of diets and assumed nutrient digestibility. Actually, the assumed digestibility is in good agreement with the determined digestibility shown in Table 3 . Further evaluation of our method requires research involving digestion trials of diets with a wider range of energy contents.

\section{References}

[1] Association of Official Analytical Chemists (1980).
Official Methods of Analysis (13th ed.), pp 132. Association of Official Analytical Chemists, Benjamin Franklin Station, Washington, D.C.

[2] Czarnecki-Maudlen, G. L., Deming, J. G., and Iz quierdo, J. V. (1989). Evaluation of practical dry dog foods suitable for all life stage. JAVMA, 195, 583590 .

[3] Finke, M. D. (1991). Evaluation of the energy requirements of adult kennel dogs. J. Nutr., 121, S22-S28.

[4] Hill, F. W. and Anderson, D. L. (1958). Comparison of metabolizable energy and productive energy determination with growing chicks. J. Nutr., 64, 587-603.

[ 5 ] Hirakawa, D. A. and Baker, D. H. (1988) . Comparative performance as well as nitrogen and energy metabolism of young puppies fed three distinctly different experimental dog foods and one commercial product. Comp. Anim. Prac., 2, 25-32.

[6] Kendall, P.T., Blaza, S. E., and Smith, P. M. (1983). Comparative digestible energy requirements of adult beagles and domestic cats for body weight maintenance. J. Nutr., 113, 1946-1955.

[7] Lloyd, L. E. (1978). Physiological fuel values. In Fundamental of Nutrition (2nd ed.), pp. 344-346, Lloyd, L. E., McDonald and Crampton, E. W. (eds), W. H. Freeman and Company, San Francisco.

[8] Maynard, L. A. (1979). Physiological fuel values. In Animal Nutrition (7th ed.), pp. 199-200, Maynard, L. A., Loosli, J. K., Hintz, H. F. and Warner, R. G. (eds), McGraw-Hill Book Company, New York.

[9] McDonald, P. (1973). Metabolisable energy. In Animal Nutrition (2nd ed.), pp. 201 203, McDonald, P., Edwards, R.A., and Greenhalgh, J. F. D. (eds), Oliver \& Void, Edinburgh.

[10] Ministry of Agriculture, Forestry and Fisheries. (1987) . Official Standard of Feed Analysis in Japan.

[11] National Research Council (1974). Composition of feeds. In Nutrient requirements of dogs, pp. 30-32, National Academy of Sciences, National Academy Press, Washington, D. C.

[12] National Research Council (1981). Definition of terms, systems used to express feed energy values and an animal's requirement for energy, and application to swine. In Nutritional Energetics of Domestic Animals and Glossary Energy Terms (2nd ed.), pp. 5-39, National Academy of Sciences, National Academy Press, Washington, D. C.

[13] National Research Council (1985). Nutrients requirements and signs of deficiency. In Nutrient requirements of dogs, pp. 2, National Academy of Sciences, National Academy Press, Washington, D. C.

[14] Suzuki, T., Shimizu, M., and Ishibashi, T. (1990). Proper energy evaluation of commercial laboratory animal diets based on digestibility and metabolizable energy values. Exp. Anim., 39, 557-564. 


\section{実験イヌ用飼料の窒素補正代謝エネルギーの推定}

大島誠之助・福間 義教・鈴木敏明・阿部又信*

日本農産工業株式会社中央研究所筑波試験場

*麻布大学獣医学部

実験イヌ用非精製飼料のエネルギー推定法である 計算式,〔代謝エネルギー=可消化エネルギー(DE) $1.25 \times$ 可消化粗蛋白質 (DCP) ) の信頼性を検討すべ く, 5 種類の飼料を 4 頭のビークル成犬に給与して, 消化試験, 窒素 $(\mathrm{N})$ 出納試験およびエネルギー価の実 測試験を行った。粗蛋白質, 粗脂肪, 可溶無窒素物の 消化率は，それぞれ79.5\%，91.6\%および84.8\%であ った。窒素出納 $(\mathrm{NB})$ はすべて正で, 捸取乾物飼料 $1 \mathrm{~g}$ 当たり 1.4 8.6mg の範囲内であった。捸取された窒 素のうち, 平均で $21 \%$ が䔬に, $66 \%$ が尿に, $13 \%$ が蓄 積に回された。飼料の総エネルギーのうち, 平均で 18 \%が䔬に，5\%が尿に排泄され，77\%が代謝エネルギ 一(ME)であった。1\%が蓄積分であり, 窒素補正代 謝エネルギー(MEn)は76\%となった。また, 尿中窒
素 $1 \mathrm{~g}$ 当たりの尿エネルギー(UE)の損失は平均で $7.84 \mathrm{kcal}$ であった。UE/DCP と NB との間には高度 の相関関係があり $(\mathrm{UE} / \mathrm{DCP}=1.24-0.03 \mathrm{NB}, \mathrm{r}=$ $0.798, \quad \mathrm{P}<0.001)$, 窒素平衡 $(\mathrm{NB}=0)$ 下では $\mathrm{UE} /$ $\mathrm{DCP}$ は $1.24 \mathrm{kcal} / \mathrm{g}$ となり, 上述の計算式の係数とほ ほ一致した。この式で求めた代謝エネルギー值は, MEn とょく一致し, 両者の值は実測 ME 值より有意 $(\mathrm{P}<0.05)$ に低かった。以上より, 上述の式は, 本来 $\mathrm{MEn}=\mathrm{DE}-1.25 \mathrm{DCP}$ と表されるべきものであり，供 試飼料の MEn を簡便に推定できる信頼性の高い式と 結論した。また, 本式はN平衡にあるイ邓はもとよ り， $\mathrm{N}$ 蓄積しているイヌに対しても適用できるこ とが立証された。 